\title{
PENGARUH PERASAN DAUN LIDAH MERTUA (Sansevieria trifasciata prain) TERHADAP ANGKA KUMAN UDARA DI RUANG KELAS R226, R221, dan R222 KAMPUS 7 POLITEKNIK KESEHATAN KEMENKES SEMARANG TAHUN 2018
}

\author{
Hadita Deni Ayu Puspitasari' ${ }^{1)}$, Teguh widyanto²), Hari Rudijanto I. W' \\ Jurusan Kesehatan Lingkungan, Politeknik Kesehatan Kemenkes Seamarang, \\ Jl.Raya Baturaden KM 12 Purwokerto, Indonesia
}

\begin{abstract}
Abstrak
Latar belakang Kualitas udara di ruang perkuliahan perlu diperhatikan karena udara menjadi media penularan penyakit. Alternatif yang bisa digunakan adalah dengan pemanfaatan perasan daun lidah mertua (Sansevieria trifasciataprain).Tanaman lidah mertua memiliki berbagai manfaat salah satunya sebagai antibakteri.Hal ini dikarenakan dalam beberapa penelitian, tumbuhan Sansevieria diketahui memiliki potensi sebagai zat antibakteri. Tujuan menganalisis pengaruh perasan lidah mertua terhadap penurunan angka kuman udara di ruang R226, R221, dan R222 Jurusan Kesehatan Lingungan Politeknik Kesehatan Kemenkes Semarang Tahun 2018. Jenis penelitian ini adalah pra eksperimen dengan rancangan pre post design. Variable bebas perasan daun lidah mertua konsentrasi 10\%,15\%, dan 25\%, variable terikat angka kuman udara. Hasil pemeriksaan angka kuman udara rata-rata sebelum perlakuan diruang 2226 didapatkan hasil 331.5 koloni/jam/feet ${ }^{2}$ dan rata setelah perlakuan $10 \% 355.33$ koloni/jam/feet ${ }^{2}$. Pada R221 angka kuman sebelum perlakuan

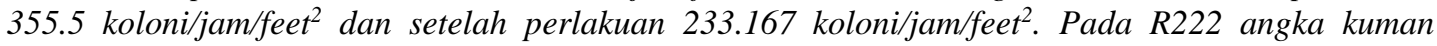
sebelum perlakuan 433 koloni/jam/feet ${ }^{2}$ dan setelah perlakuan sebesar 225.5 koloni/jam/feet ${ }^{2}$. Dosis efektif perlakuan $(10 \%, 15 \%$ dan 25\%) terhadap penurunan angka kuman udara ruang R226, R221 dan R222 adalah konsentrasi $15 \%$ sebesar $57.67 \%$ dalam $4 \mathrm{ml} / \mathrm{m}^{3}$. Simpulan dari hasil penelitian bahwa secara statistik pemakaian perasan lidah mertua tidak ada pengaruh terhadap penurunan angka kuman udara di ruang kelas R226, R221 dan R222 Jurusan Kesehatan Lingkungan Politeknik Kesehatan Kemenkes Semarang. Disarankan sebaiknya meningkatkan kebersihan perilaku pengguna ruangan, lantai dibersihkan menggunakan antiseptik, membuka jendela dipagi hari sebelum menyalakan AC, dan untuk peneliti selanjutnya sebaiknya menggunakan butiran mist dengan konsentrasi perasan yang lebih tinggi.
\end{abstract}

Kata kunci : Angka Kuman Udara; Lidah Mertua; Kesehatan Lingkungan

\begin{abstract}
Backgound Air quality in the lecture hall needs to be considered because the air becomes a medium of disease transmission. The alternative that can be used is with the use of the leaves of the tongue-in-law (Sansevieria trifasciataprain). Plant Sansevieria has many benefits one of them as antibacterial. This is because in some studies, Sansevieria plants are known to have potential as an antibacterial agent. The purpose of this research is to analyze the sansevieria juice on the decrease of air bacteria in room R226, R221, and R222 Health Department of Health Polytechnic Kemenkes of Semarang in 2018. This type of research is pre experiment with pre post design design. The free varieties of sansevieria leaves infusion concentration of 10\%, 15\%, and 25\%, variable bound to air bacteria. The results of the average air bacteria examination before the treatment room 226 obtained 331.5 colonies / hour / feet ${ }^{2}$ and average after treatment of $10 \% 355.33$ colonies / hour / feet2. In R221 air bacteria before treatment 355.5 colonies / hour / feet ${ }^{2}$ and after treatment of 233,167 colonies / hour / feet ${ }^{2}$. In R222 air bacteria prior to treatment of 433 colonies / hour / feet ${ }^{2}$ and after treatment of 225.5 colonies / hour / feet ${ }^{2}$. The effective dose of treatment $110 \%, 15 \%$ and $25 \%$ ) on the decrease of air space bacteria R226, R221 and R222 was $15 \%$ concentration of $57.67 \%$ in $4 \mathrm{ml} / \mathrm{m} 3$. Conclusions from the results of the study that statistically the use of sansevieria juice no effect on the reduction of airborne bacteria in the classroom R226, R221 and R222 Environmental Health Department of Health Polytechnic Kemenkes Semarang. It is advisable to improve the cleanliness of the user's room behavior, the floor is cleaned with antiseptic, open the window in the morning before turning on the air conditioner, and for the next researcher it is better to use misty grain with higher concentration.
\end{abstract}

Key words : air bacteria level; air pollution; sansevieria 


\section{Pendahuluan}

Udara dapat dikelompokkan menjadi, udara luar ruangan (outdoor air) dan udara dalam ruangan (indoor air). Kualitas udara dalam ruang sangat mempengaruhi kesehatan manusia karena hampir $90 \%$ hidup manusia berada dalam ruangan.Sebanyak 400 sampai 500 juta orang khususnya di negara yang sedang berkembang sedang berhadapan dengan masalah polusi udara dalam ruangan. Di Amerika, isu polusi udara dalam ruang ini mencuat ketika Enviromental Protection Agency (EPA) pada tahun 1989 mengumumkan studi polusi udara dalam ruangan lebih berat daripada di luar ruangan.Pencemaran udara dalam ruangan menurut penelitian The National Institute of Occupational Safety and Health (NIOSH) sumbernya antara lain dari kegiatan penghuni (asap rokok dan bahan kimia untuk keperluan rumah tangga) dan pencemar dari luar (gas buangan kendaraan bermotor, cerobong asap dapur, asap buangan industri). Pencemaran tersebut dapat mengakibatkan Sindom bangunan sakit (SBS). Beberapa gejala yang paling sering dilaporkan adalah sakit kepala, iritasi mata, hidung dan tenggorokan, rasa lelah, dan mual.

Menurut laporan Organisasi Kesehatan Dunia (WHO) pada tahun 1984, terdapat 30\% bangunan baru dan terenovasi yang terkait dengan gejala-gejala SBS. Sebagian besar gejala sindrom bangunan sakit disebabkan oleh kualitas udara di dalam ruangan yang buruk.Untuk mengatasi masalah angka kuman di udara guna meminimalisir, menghambat, dan membunuh kuman udara agar angka kuman udara antara lain yaitu desinfeksi (pengaplikasian bahan kimia/ desinfektan seperti alkohol dan klorin), sterilisasi, pengendalian dengan radasi sinar ultraviolet (UV) dan sinar ionisasi serta pengendaian dengan filtrasi. (Jensen, 1998).Selain itu menggunakan ozon pada penelitian Tofik Nurohim (2015). Penggunaanbahan kimia dengan terus menerus bahkan berulang serta dalam jangka waktu yang lama justru dapat mengakibatkan resistensi kuman. Alternatif yang bisa digunakan sebagai pengganti yaitu menggunakan desinfektan biologi atau alami yang lebih ramah lingkungan.

\footnotetext{
1) E-mail: Hadita.deni@gmail.com

2) E-mail: widyantoteguh@yahoo.co.id

3) E-mail: Hariokey2000@gmail.com
}

Salah satu tumbuhan yang diindikasikan. dapat dijadikan alternatif sebagai antibakteri adalah tumbuhan Sansevieria. Tumbuhan Sansevieria memiliki berbagai manfaat salah satunya sebagai antibakteri. Hal ini dikarenakan dalam beberapa penelitian, tumbuhan Sansevieria diketahui memiliki potensi sebagai zat antibakteri. Hasil fraksinasi yang mengandung senyawa steroid menunjukkan adanya aktivitas penghambatan pertumbuhan antibakteri hanya pada Staphylococcus aureus dengan konsentrasi 10000, 20000, dan 40000 ppm.Gitasari, Yanditya Dwastu. (2011). Disebutkan bahwa Kandungan yang terdapat di dalam Sanvieria Hasil uji fitokimia ekstrak daun Sansevieria trifasciata Prain Golongan senyawa Hasil uji Saponin Tanin Flavonoid, Steroid, Triterpenoid Alkaloid. Berdasarkan Studi dari Jurusan Kesehatan lingkungan Poltekkes Kemenkes Pontianak tahun 2015 menyatakan bahwa rata-rata penurunan jumlah mikroba pada ruang kelas yang diberi tanaman Lidah Mertua sebesar $132,96 \mathrm{cfu}$.

Lokasi penelitian berada di ruang R226, R221, dan R222 kampus 7 Poltekkes Kemenkes Semarang. Ruang R226, R221 dan R222 merupakan ruang kelas Jurusan Kesehatan Lingkungan nerupakan ruangan yang digunakan untuk kegiatan perkuliahan dan berpotensi mengalami pencemaran udara, dalam hal ini adalah kuman udara. Ruang tersebut digunakan untuk kegiatan belajar mengajar dengan ratarata penggunaan ruang selama 8 jam per hari. Pada ruang kelas terdapat AC sehingga ventilasi tidak terbuka guna memaksimalkan kinerja AC sedangkan pencahayaan yang digunakan adalah pencahayaan buatan. Metode pembersihan ruangan yang dilakukan dari hasil pengamatan hanya dilakukan penyapuan dan tidak ada sterilisasi ruangan. 1. Tujuan Umum

Tujuan pada penelitian ini menghitung angka kuman di udara pada udara ruang kelas R226, R221, dan R222 jurusan Kesling Purwokerto setelah diberi perlakuan perasan daun lidah mertua (Sanvieria trifasciata prain) dengan konsentrasi 10\%, 15\%, 25\%

\section{Metode Penelitian}

a. Prosedur Pembuatan Perasan Daun Lidah Mertua

Diambil daun lidah mertua yang berwarna hijau,sehat,tidak berluang kemudian dicuci dengan air mengalir, dipotong-potong dan blinding daun lidah 
mertua yang telah dipotong-potong menggunakan blender hingga halus Selanjutnya disaring dengan kain kasa steril, tambahkan aquades dengan konsentrasi yang diinginkan $(10 \%, 15 \% .25 \%)$. Komposisi yang digunakan untuk 100ml larutan konsentrasi $10 \%$ perasan daun lidah mertua antara lain $10 \mathrm{ml}$ perasan daun lidah mertua dan $90 \mathrm{ml}$ aquades dan untuk $100 \mathrm{ml}$ larutan konsentrasi $15 \%$ perasan daun lidah mertua antara lain $15 \mathrm{ml}$ perasan daun lidah mertua dan $85 \mathrm{ml}$ aquades sedangkan untuk $100 \mathrm{ml}$ larutan konsentrasi $25 \%$ perasan daun lidah mertua antara lain $25 \mathrm{ml}$ perasan daun lidah mertua dan $75 \mathrm{ml}$ aquades.

b. Prosedur pelaksanaan desinfeksi ruangan

Lakukan prosedur ini setelah dilakukan pengukuran angka kuman udara sebelum diberi perlakuan, Siapkan ruangan yang akan di desinfeksi (ruang R226, R221, dan R222 Jurusan Kesehatan Lingkungan), Siapkan hasil perasan tanaman lidah mertua dan botol spraynya, Lakukan perhitungan volume desinfeksi (air perasan tanaman lidah mertua) yang dibutuhkan untuk ruang R226, R221, dan R222 dengan asumsi volume ruangan 201,42 $\mathrm{m}^{3}$ dan setiap $1 \mathrm{~m}^{3}$ terpakai $4 \mathrm{ml}$ (dosis penelitian adalah $4 \mathrm{ml} / \mathrm{m}^{3}$ sehingga volume desinfektan yang dipakai dalam ruang R226, R221, dan R222 sebanyak $805.68 \mathrm{ml}$, Masukkan larutan tersebut ke dalam botol spray menggunakan corong, Lakukan penyemprotan ke atas kiri dan kanan dengan cara mundur menuju pintu keluar, Tunggu sampai kontak 2 jam, Lakukan perhitungan angka kuman udara kembali setelah 2 jam penyemprotan tersebut.

\section{c. Prosedur pengukuran angka kuman}

Tentukan lokasi penelitian, Bersihkan tangan pengambil sampel dan meja tempat pengambilansampel, Letakkan media dalam cawan secara terbuka dan paparkan selama \pm 30menit, Tutup media tersebut dan inkubasikan selama 2 × 24 jam pada suhu $\pm 370 \mathrm{C}$ didalam inkubator dengan keadaan cawan terbalik, Amati pertumbuhan mikroba dan catat hasilnya menggunakan rumus jumlah kuman di udara ruang :

$=\sum$ kol percawan $X \frac{60 \text { menit }}{30 \text { menit }} X \frac{144 \text { in }^{2}}{\text { luas cawan }\left(\text { in }^{2}\right)}$
$=\ldots \ldots \ldots \frac{\text { koloni }}{\text { jam }} /$ Feet $^{2}$

\section{d. Jenis Penelitian}

Penelitian pre experimental dengan One Group Pretest Posttest Design. subyek penelitian terlebih dahulu diukur angka kuman udara awal (pre test) untuk mengetahui angka kuman udara sebelum diberikan perlakukan perasan tanaman lidah mertua. Setelah itu diberikan perlakuan, yaitu penyemprotan perasan tanaman lidah mertua. Selanjutnya dikontakkan selama 2 jam kemudian diukur angka kuman udara (post test) pada ruang R226, R221, dan R222 sebanyak 3 kali untuk mengetahui pengaruh angka kuman udara setelah diberikan perlakuan perasan tanaman lidah mertua. Prosedur pemeriksaan dan pengamatan laboratorium jumlah kuman udara ruang R226, R221, dan R222 kesling Purwokerto dengan menggunakan media PCA. Pengukuran suhu udara, kelembapan udara, pencahayaan dan lama kontak menggunakan Thermometer, Hygrometer, dan Luxmeter.

Data hasil penelitian dianalisis perbedaan angka kuman udara sebelum dan sesudah diberi perlakuan yaitu uji Pair $T$ test dan untuk mengetahui ada beda yang bermakna antar variasi konsentrasi perasan lidah mertua konsentrasi $10 \%, 15 \%$ dan $25 \%$ menggunakan Uji Analisis of Variance (ANOVA).

\section{Hasil dan Pembahasan}

\section{a. Menentukan Dosis Efektif}

Kemudian dianalisis dosis efektif perlakuannya dalam $4 \mathrm{ml} / \mathrm{m}^{3}$.

Persentase efektivitas perlakuan dihitung menggunakan rumus $=$

$\left(\frac{\text { Kelompok Post test }- \text { Kelompok Pre Test }}{\text { Kelompok Pre Test }}\right) \times 100 \%$

Tabel 1 Efektivitas Dosis Perasan Daun Lidah Mertua Terhadap Angka Kuman Udara di Ruang R226, R211, dan R222 Juusan Kesling Tahun 2018

\begin{tabular}{l|l|l|l|l}
\hline \multirow{2}{*}{ Ruang } & $\begin{array}{c}\text { Waktu / } \\
\text { Replikasi } \\
\text { ke- }\end{array}$ & $\begin{array}{c}\text { Angka } \\
\text { kuman } \\
\text { udara } \\
\text { sebelum }\end{array}$ & $\begin{array}{c}\text { Angka } \\
\text { kuman } \\
\text { udara } \\
\text { sesudah } \\
\text { perlakuan }\end{array}$ & $\begin{array}{c}\text { Efektivita } \\
\text { s (\%) }\end{array}$ \\
\hline R226 & $\begin{array}{l}\text { Pre / } \\
\text { Replikasi } \\
\text { ke 1 }\end{array}$ & 248 & 350 (Post1) & 41,13 \\
\cline { 2 - 5 } & & & 96 (Post 2) & $-61,29$ \\
\cline { 2 - 5 } & $\begin{array}{l}\text { Pre } \\
\text { Replikasi } \\
\text { ke 2 }\end{array}$ & 415 & 150 (Post 3) & $-39,51$ \\
\cline { 2 - 5 } & & & ) & 202,169 \\
\hline
\end{tabular}




\begin{tabular}{|c|c|c|c|c|}
\hline & & & 272 (Post3) & $-34,45$ \\
\hline \multicolumn{5}{|c|}{ Rata-rata Efektifitas 1.338} \\
\hline \multirow[t]{6}{*}{ R221 } & $\begin{array}{l}\text { Pre I } \\
\text { Replikasi } \\
\text { ke 1 }\end{array}$ & 443 & 260 (Post1) & $-41,31$ \\
\hline & & & 293 (Post2) & $-33,86$ \\
\hline & & & 0 (Post3) & -100 \\
\hline & $\begin{array}{l}\text { Pre I } \\
\text { Replikasi } \\
\text { ke 2 }\end{array}$ & 423 & 341(Post1) & $-19,38$ \\
\hline & & & 69(Post2) & $-83,68$ \\
\hline & & & 390 (Post3) & $-7,80$ \\
\hline \multicolumn{5}{|c|}{ Rata-rata Efektifitas -47.67 } \\
\hline \multirow[t]{6}{*}{ R222 } & $\begin{array}{l}\text { Pre I } \\
\text { Replikasi } \\
\text { ke 1 }\end{array}$ & 337 & 289 (Post1) & $-14,24$ \\
\hline & & & 313 (Post2) & $-7,12$ \\
\hline & & & 28 (Post3) & $-91,38$ \\
\hline & $\begin{array}{l}\text { Pre I } \\
\text { Replikasi } \\
\text { ke 2 }\end{array}$ & 374 & 224 (Post1) & $-40,10$ \\
\hline & & & 236 (Post2) & $-36,89$ \\
\hline & & & 309 (Post1) & $-17,38$ \\
\hline
\end{tabular}

Keterangan :

Angka kuman setelah atau sebelum perlakuan menggunakan satuan koloni/jam/feet ${ }^{2}$

diketahui bahwa dosis perlakuan efektif dalam $4 \mathrm{ml} / \mathrm{m}^{3}$ pemakaian perasan daun lidah metua (Sansevieria trifaciata prain) terhadap angka kuman udara ruang kelas R226, R221, dan R222 tertinggi hingga terendah secara berurutan yaitu konsentrasi $15 \%$ dengan persentase rata-rata efektivitas $-47,67 \%$, kemudian konsentrasi $25 \%$ dengan persentase rata-rata efektivitas $-34,57 \%$ dan konsentrasi 10 $\%$ dengan nilai persentase rata-rata efektivitas terendah yaitu $1,338 \%$

\section{b. Wawancara}

Berdasarkan hasil wawancara dengan petugas kebersihan didapatkan informasi mengenai upaya menjaga kebersihan ruang antara lain, ruangan dibersihkan sekali dalam sehari yakni saat perkuliahan belum di mulai. Ruangan dilakukan pengepelan dikalau dirasa perlu atau saat ruangan dalam keadaan kotor. Pengepelan menggunakan desinfektan, desinfeksi yang digunakan yakni cairan pembersih lantai yang ada di pasaran. petugas tidak membuka jendela dipagi hari.

Hasil wawancara dapat diketahui bahwa petugas kebersihan melakukan pembersihan ruangan secara ruitn dengan menyapu ruangan namun tidak melakukan pengepelan secara rutin serta tidak dilakukan pengendalian untuk menjaga sirkulasi udara dengan tidak membuka jendela. Jendela sebaiknya dbuka dipagi hari agar terjadi pertukaran udara dari dalam keluar luar ruangan. Jendela dibuka sampai beberapa saat untuk kemudian AC dinyalakan. c. Pengukuran Dan Pemeriksaan Angka Kuman Udara Di Ruang R226 R221, dan R222 Sebelum Dan Sesudah Perlakuan Perasan Daun Lidah Mertua (Sansevieria trifaciata prain)

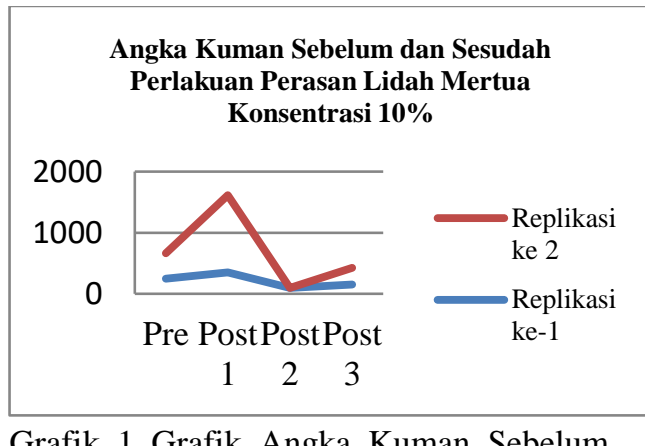

Grafik 1 Grafik Angka Kuman Sebelum dan Sesudah Perlakuan Perasan Lidah Mertua Konsentrasi 10\%

Angka kuman udara dalam ruang kelas dipengaruhi jumlah penghuni, aktivitas penghuni kemudian suhu dan kelembapan udara,sirkulasi udara yang kurang lancar, kerbersihan filter AC maupun kipas angin serta keadaan korden yang tidak pernah dibersihkan menyebabkan debu dan mikroba udara menempel. Hasil pemeriksaan angka kuman udara di ruangan R226 pada replikasi ke 2 didapatan rata-rata post 508,7 koloni/jam/feet ${ }^{2}$ jika dibandingkan dengan nilai Pre sebesar 415 koloni/jam/feet ${ }^{2}$ terjadi kenaikan angka kuman kerana pengambilan angka terjadi puncak aktivitas dengan kegiatan presentasi pada mata kuliah. meningkatnya kadar $\mathrm{CO}_{2}$ di udara sehingga kualitas udara dalam ruang menurun. $\mathrm{CO}_{2}$ sebagai sumber karbon utama sehingga terjadi peningkatan angka kuman udara.

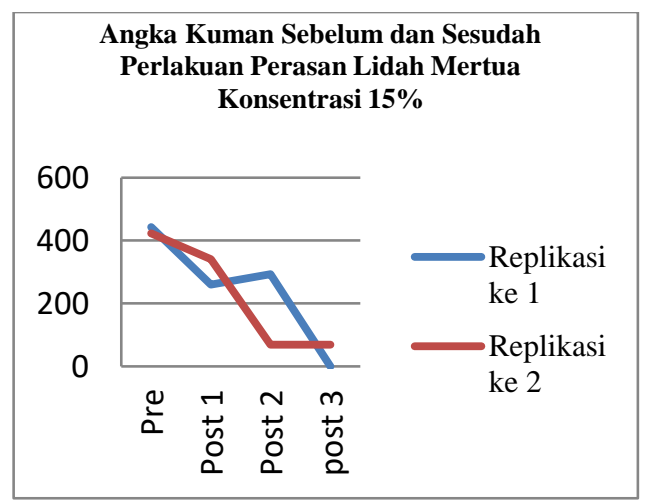

Grafik 2 Grafik Angka Kuman Sebelum dan Sesudah Perlakuan Perasan Lidah Mertua Konsentrasi 15\% 
Hasil pemeriksaan angka kuman di ruangan R221 dari sebelum perlakuan dan sesudah perlakuan mengalami penurunan baik pada replikasi 1 dan 2 adapun terjadinya aktivitas mikroba dipengaruhi oleh lingkungan. Menurut Lud Waluyo (2007) Tingkat pencemaran di dalam ruangan oleh mikroba dipengaruhi oleh faktor-faktor seperti laju ventilasi, padatnya orang, sifat, dan taraf kegiatan orang yang menempati ruangan tersebut. Mikroba terhembuskan dalam bentuk percikan dari hdung dan mulut selama bersin, batuk dan bercakap-cakap. Debu dari permukaan ini sebentar-sebentar akan berada udara selama berlangsungnya kegiatan dalam ruangan tersebut.

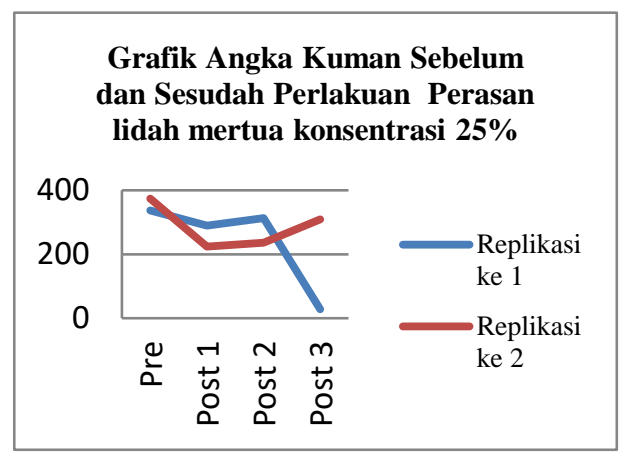

Grafik 3 Grafik Angka Kuman Sebelum dan Sesudah Perlakuan Perasan Lidah Mertua Konsentrasi 25\%

Hasil pemeriksaan angka kuman di ruangan R221 dari sebelum perlakuan dan sesudah perlakuan mengalami penurunan baik pada replikasi 1 dan 2. pada replikasi 2 post 3 terjadi peningkatan dikarenakan pada saat pengambilan angka kuman udara berlangsung kondisi kelas aktif, aktivitas penghuni datang ketika media sudah terpasang dan dengan menyalakan kipas angin serta AC. Menurut Aditama (2002) menyatakan bahwa pencemaran kuman udara dapat berasal dari dalam gedung dengan sumber pencemaran diantaranya aktivitas dalam ruangan, frekuensi keluar masuk ruangan yang tinggi sehingga memungkinkan masuknya polutan dari luar ke dalam ruangan, penggunaan pengharum ruangan, asap rokok, penggunaan pestisida dan pembersih ruangan, mesin fotokopi, sirkulasi udara yang kurang lancar, suhu dan kelembapan udara yang tidak nyaman (Corie Indria Prasasti, 2005, h.6).
Menurut Lud Waluyo (2007) Faktorfaktor yang mempengaruhi pertumbuhan jasad renik yang bersifat heterotrof adalah tersedianya nutrient, air, suhu, $\mathrm{pH}$, Oksigen, dan potensial oksidasi reduksi, adanya zat-zat penghambat, dan adanya jassad renik yang lain.

\section{d. Uji Paired T test}

Pada pemakaian perasan daun lidah mertua (Sansevieria trifaciata prain) konsentrasi $10 \%$, Nilai sig 0,423 pada post 1 , nilai sig 0,276 pada post 2 , dan nilai sig 0,118 pada post 3 . Jika nilai sig $>\alpha$, maka Ho diterima dan ha ditolak berarti tidak ada perbedaan angka kuman udara di Ruang R226 Jurusan Kesling sebelum dan sesudah diberi perlakuan konsentrasi $10 \%$ perasan lidah mertua (Sansevieria trifaciata prain).

Pada pemakaian perasan daun lidah mertua (Sansevieria trifaciata prain) konsentrasi $15 \%$ didapatkan Nilai sig 0,232 pada post 1 , nilai sig 0,245 pada post 2 , dan nilai sig 0,453 pada post 3 . Jika nilai sig $>\alpha$, maka Ho diterima dan ha ditolak berarti tidak ada perbedaan angka kuman udara di Ruang R221 Jurusan Kesling sebelum dan sesudah diberi perlakuan konsentrasi $15 \%$ perasan lidah mertua (Sansevieria trifaciata prain)

Pada pemakaian perasan daun lidah mertua (Sansevieria trifaciata prain) konsentrasi $25 \%$, Nilai sig 0,303 pada post 1 , nilai sig 0,390 pada post 2 , dan nilai sig 0,368 pada post 3 . Jika nilai sig $>\alpha$, maka Ho diterima dan ha ditolak berarti tidak ada perbedaan angka kuman udara di Ruang R222 Jurusan Kesling sebelum dan sesudah diberi perlakuan konsentrasi $25 \%$ perasan lidah mertua (Sansevieria trifaciata prain).

Sebagai alternatif yaitu menggunakan desinfektan alami yang lebih ramah lingkungan salah satunya dengan pemanfaatan larutan hasil perasan daun lidah mertua (Sansevieria trifaciata prain). Berdasarkan pengukuran angka kuman di ruang R221, R222 dan R226 sebelum dan sesudah diberi perlakuan perasan daun lidah mertua (Sansevieria trifaciata prain) didapatkan hasil $15 \%$ dan $25 \%$ perasan daun lidah mertua menunjukan adanya penurunan angka kuman udara setelah diberi perlakuan perasan daun lidah mertua (Sansevieria trifaciata prain). Meskipun berdasarkan uji analisis statistik pada analisis perbedaan angka kuman udara sebelum dan setelah diberi perlakuan tidak menunjukan penurunan 
yang signifikan. Hal ini antara lain dipengaruhi oleh aktivitas penghuni ruang sebagai penghasil kuman yang bervariasi, faktor yang mempengaruhi dan tidak dapat dihindarkan antar lain seperti suhu dan kelembapan.

Hasil pengukuran angka kuman yang fluktuatif dikarenakan perasan daun lidah mertua memilki daya hambat bakteri atau antibakteri pada beberapa jenis mikroba antarlain jenis kuman udara Stappylococcus sedangkan dalam penelitian ini menggunakan metode hitungan cawan dengan menggunakna media PCA sehingga dalam penelitian ini tidak dapat diketahui jenis mikroba yang masih hidup ditumbuhkan pada medium.Upaya yang dilakukan agar angka kuman udara tetap turun, perasan daun lidah mertua dilakukan pembuatan larutan dengan konsentrasi lebih tinggi dan penyemprotan dengan menggunakan butiran mist agar larutan merata di seluruh ruangan.

\section{e. Uji multivariat}

Berdasarkan hasil uji analisi statistik pada analisis perbedaan penurunan angka kuman udara di ruang R221, R222, dan R226 Jurusan Kesehatan Lingkungan antara perasan daun lidah mertua (Sansevieria trifaciata prain) konsentrasi $10 \%, 15 \%$ dan $25 \%$ didapatkan hasil dari Test of Homogeneity of Variences menunjukan bahwa nilai sig $<\alpha$ yaitu $0,046<0,05$. jika nilai sig $<\alpha$ maka ha ditolak artinya data varians tidak homogeny, sehingga data tidak bisa dilanjutkan menggunakan uji One Way Anova melainkan menggunakan uji statistik non-parametrik yaitu Kruskal Wallis.

Hasil uji analisis menggunakan uji Kruskal Wallis didapatkan nilai sig 0,774. Nilai sig $>\alpha$ yaitu $0,774>0,05$. jika nilai $\operatorname{sig}>\alpha$, maka Ha ditolak berarti tidak ada perbedaan penurunan angka kuman udara di ruang R221 jurusan Kesehatan Lingkungan antara pemakaian perasan daun lidah mertua $(10 \%, 15 \%$ dan $25 \%)$

Uji analisis statistik pada analisis perbedaan penurunan angka kuman udara di ruang R226, R221 dan R222 Jurusan Kesehatan Lingkungan antara person daun lidah mertua (Sansevieria trifaciata prain) konsentrasi $10 \%, 15 \%$, dan $25 \%$ didapatkan hasil bahwa tidak ada perbedaan penurunan yang signifikan antar konsentrasi. Hal ini karena perbedaan jarak antar konsentrasi sedikit serta jumlah penghuni ruang yang menyebabkan meningkatnya jumlah kuman udara di dalam ruang. Sehingga perlu peningkatan diperbesar antar rentang angka konsentrasi agar terjadi perbedaan yang signifikan antar konsentrasi serta peningkatan konsentrasi perasan daun lidah mertua.

\section{f. Kesimpulan dan Saran}

Simpulan Dosis efektif perlakuan $(10 \%, 15 \%$ dan $25 \%$ ) terhadap penurunan angka kuman udara ruang R226, R221 dan R222 adalah konsentrasi $15 \%$ sebesar 57,67 \% dalam $4 \mathrm{ml} / \mathrm{m}^{3}$. Disimpulkan bahwa tidak ada perbedaan angka kuman di ruang R226, R221 dan R222 Jurusan Kesehatan Lingkungan diberi perlakuan dan sesudah perlakuan konsentrasi $10 \%, 15 \%$, dan $25 \%$ perasan daun lidah mertua (Sansevieria trifaciata prain). Hasil nilai $\mathrm{t}$ negative (-) menunjukan adanya penurunan anga kuman udara setelah diberi perlakuan perasan daun lidah mertua (Sansevieria trifaciata prain).

Hasil analisis perbedaan penurunan angka kuman udara di ruang R226, R221 dan R222 Jurusan Kesehatan Lingkungan antara pemakaian perasan daun lidah mertua $10 \%, 15 \%$ dan $25 \%$ menggunakan uji Kuskall wallis nilai sig $>\alpha$ yaitu $0,774>0,05$. maka tidak ada perbedaan penurunan yang signifikan antar pemakaian konsentrasi $10 \%, 15 \%$, dan $25 \%$ perasan daun lidh mertua (Sansevieria trifaciata prain).

Saran Bagi Instansi Kampus 7 Poltekkes Kemenkes Semarang : Bagi instasi kampus 7 Poltekkes kemenkes Semarang Tindakan yang perlu dilakukan agar angka kuman di dalam udara ruang tidak melebihi batas persyaratan yaitu meningkatkan kebersihan perilaku pengguna ruangan, lantai dibersihkan menggunakan antiseptik, membuka jendela dipagi hari sebelum perkuliahan dimulai agar terjadi sirkulasi udara dan melakukan pembersihan secara berkala, serta menjaga kebersihan kipas angin. Bagi Peneliti : Peneliti selanjutnya yang melakukan penelitian sejenis dapat meneliti menggunakan penyemprotan dengan butiran mist dengan konsentrasi yang lebih tinggi. 


\section{Daftar Pustaka}

A. Aziz Alimatul H.2007. Metode Penelitian Kebidanan Teknik analisis data. Jakarta : Salemba Medika

Aditama Tjandra Y, 2002, Kesehatan dan Keselamatan Kerja, Jakarta: University Press

Arie W. Purwanto. 2010. Sansevieria Flora Canti Penyerap Racun. Yogyakarta: kanikus

Brily Lombogia. dkk. 2016. Uji daya hambat ektrak daun lidah mertua (Sansevieriae trifasciata folium) terhadap pertumbahan bakteri Escherichia coli dan streptococcus sp. Manado : Fakultas Kedokteran Universitas sam Ratulang Manado.

Dumanauw Jovie Mien. dkk. 2015. Penetapan Kadar Saponin Pada Ekstrak Daun Lidah Mertua (Sansevieria Trifasciata Prain Varietas S. Laurentii) Secara Gravimetri. Manado: Jurusan Farmasi Politeknik Kesehatan Kemenkes Manado

Eka Puspita Sari. dkk. 2015, Analisis Peran Dari Tanaman Lidah Mertua (Sanseveria) Dan Tanaman Sri Rejekt (Aglaonema) Dalam Menurunikan Mikroba Udara Ruang Kelas JKL Poltekkes Kemenkes Pontianak, Pontianak: Kementerian Kesehatan Republik Indonesia Politeknik Kesehatan Kemenkes Pontianak.

Evi Wulandari. 2013, Faktor Yang Berhubungan Dengan Keberadaan Streptococcusdi Udarapada Rumah Susun Kelurahan Bandarharjo Kota Semarang Tahun 2013 , Semarang: Jurusan Ilmu Kesehatan

Felisia Anita Nuhan. 2015. Skrining Antibakteri Kombinasi Ekstrak Etanol Temulawak, Meniran, Kemukus Dan Beluntas Terhadap Staphylococcus Aureus, Escherichia Coli Dan Salmonella Typhi. Surabaya. Fakultas Farmasi Universitas Katolik Widya Mandala Surabaya.

Retno Ningrum dkk. 2016. Identifikasi Senyawa Alkaloid Dari Batang Karamunting (Rhodomyrtus Tomentosa) Sebagai Bahan Ajar Biologi Untuk Sma Kelas X. Malang. Pendidikan Biologi FKIP Universitas Muhammdiyah Malang

Rizka Tiara V. 2016. Kondisi fisik dan jumlah bakteri udara pada ruangan $\mathrm{AC}$ dan non $\mathrm{AC}$
Masyarakat Fakultas Ilmu Keolahragaan Universitas Negeri Semarang.

https://en.wikipedia.org/wiki/Sansevieria_trifasciat a, diakses tanggal 28-12-2017

http://file.upi.edu/Direktori/FPMIPA/JUR._PEND. _MATEMATIKA/195909221983031YAYA_SUKJAYA_KUSUMAH/Pengertia n_Variabel_Penelitian.pdf, diakses tanggal 02-01-2018

http://www.menulisproposalpenelitian.com/2010/1 0/variabel-pengganggu-dalampenelitian.html? $\mathrm{m}=0$, diakses pada tanggal 02-01-2018

Indan Entjang. 2003. Mikrobiologi dan Parasitologi, Bandung: PT Citra Aditya Bakti

Keputusan Menteri Kesehatan Republik Indonesia Nomor 1335/MENKES/SK/X/2002

Tentang Standar Operasional Pengambilan dan Pengukuran Sampel Kualitas Udara Ruangan Rumah Sakit.

Kesling.poltekkes-smg.ac.id , diakses tanggal 2-42018

Lud Waluyo. 2004. Mikrobiologi Umum. Malang: Universitas Muhammdiyah Malang

Merlin. 2012. Studi Kualitas Udara Mikrobiologi Denganparameter Jamur Pada Ruangan Pasien Rumah Sakit (Studi Kasus: Ruang Rawat Inap Gedung A Rumah Sakit Pusat Nasional Dr. Cipto Mangunkusumo), Depok: Fakultas Teknik Program Studi Teknik Lingkungan Univresitas Indonesia

di sekolah dasar. Semarang : Universitas Muhammadiyah Semarang

Siti Laela Qomariyah. 2011. Studi Komparasi Angka Kuman Udara Sebelum Dan Sesudah Desinfeksi Dengan Bahan Didecyldimethylammonium Chloride Di Kamar Isolasi Ruang Soka Rsud Prof. Dr. Margono Soekarjo Purwokerto Tahun 2011. Purwokerto: Kementerian Kesehatan Republik Indonesia Politeknik Kesehatan Kemenkes Semarang Jurusan Kesehatan Lingkungan Purwokerto

Taufik Nurohim. 2016, Pengaruh Penggunaan Ion Plasma dengan Penurunan Jumlah Angka Kuman Udara pada Instalasi Ruag Rawat 
Inap 1 (IRNA 1) RSUD Prof. Dr. Margono Soekarjo Purwokerto Tahun 2016, Purwokerto: Kementerian Kesehatan Republik Indonesia Politeknik Kesehatan Kemenkes Semarang Jurusan Kesehatan Lingkungan Purwokerto

Tri Cahyono. 2017. Penyehatan Udara. Yogyakarta: Penerbit Andi

Tri Cahyono, 2014. Pedoman Penulisan Proposal Penelitian dan Karya Tulis Ilmiah / Skripsi (Edisi Revisi Ketiga), Purwokerto: Kementerian Kesehatan Republik Indonesia Politeknik Kesehatan Kemenkes Semarang Jurusan Kesehatan Lingkungan Purwokerto. Malang:Universitas Muhammadiyah Malang

Paul, M. J dan E. C. S. Chan. 2008. Dasar-Dasar Mikrobiologi Jilid ke-1. Jakarta: Penerbit UI Press

Peraturan Menteri Kesehatan Nomor 48 Tahun 2016 Tentang Standar Keselamatan dan Kesehatan Kerja Perkantoran
Wulan Cendana Arum. 2016, Pengaruh Pemakaian Perasan Daun Jeruk Nipis (Citrus aurantifolia) Terhadap Angka Kuman Udara Ruang Kelas R221 Jurusan Kesling Purwokerto Tahun 2016, Purwokerto: Kementerian Kesehatan Republik Indonesia Politeknik Kesehatan Kemenkes Semarang Jurusan Kesehatan Lingkungan Purwokerto

Yanditya Dwastu Gitasari. 2011, Aktivitas Antibakteri Fraksi Aktif Daun Lidah Mertua (Sansevieria trifasciata prain), Bogor: Fakultas Matematika Dan Ilmu Pengetahuan Alam Intitut Pertanian Bogor

Yusizal, dkk. 2013, Sanseparfum: Komersialisasi Produk Inovatif Pengharum Ruangan Ramah Lingkungan Dari Daun Lidah Mertua (Sansevieria), Bogor: Institut Pertanian Bogor

https://id.wikipedia.org/wiki/Karangmangu,_Batura den,_Banyumas diakses pada tanggal 4-042018 